\title{
Robert Koch: centenary of the discovery of the tubercle bacillus, 1882
}

\author{
ALEX SAKULA \\ From Redhill General Hospital, Surrey
}

ABSTRACT This is an account of the life and work of Robert Koch (1843-1910), Nobel Laureate in Medicine and a founder of the science of bacteriology. In particular, Koch's researches into tuberculosis are described-the discovery of the tubercle bacillus, the controversy regarding the human and bovine types, the Koch phenomenon, and the introduction of tuberculin, which proved to be ineffective as a cure but became important as a diagnostic tool in the management of tuberculosis. By his achievements in this field, Koch may be considered to be the father of the scientific study of tuberculosis. On the occasion of the centenary of Koch's discovery of the tubercle bacillus in 1882, we pay tribute to this great German master of medicine.

Robert Koch's discovery of the tubercle bacillus in 1882 was a major event in the history of medicine, a turning point in our understanding and conquest of that deadly disease which had plagued mankind for millenia. After centuries of speculation as to the possible infectious nature of tuberculosis, Koch proved conclusively that the cause of the disease was infection by a specific micro-organism which he isolated. In tuberculosis, both seed and soil play their part, but without the seed-the tubercle bacillus-there is no disease.

On the occasion of the centenary of Koch's discovery of the tubercle bacillus, we pay tribute to the father of the modern scientific approach to the management of tuberculosis.

\section{Life of Robert Koch}

Robert Koch, the son of a mining engineer, was born on 11 December 1843, in Clausthal, a village in the Harz mountains. In 1862, he began his medical studies at Göttingen University, where he came under the influence of Jacob Henle. In 1866 he qualified maxima cum laude with an MD thesis on succinic acid. For a time he was in general practice in Rakwitz, but in 1871, during the Franco-Prussian war, he served with the German Army. On his discharge in 1872, he became district physician in Wollheim, and it was here that his wife presented him with a microscope on his birthday, and he set up a primitive laboratory and began his study of

Address for reprint requests: Redhill General Hospital, Earlswood Common, Redhill, Surrey RH1 6LA. infectious disease. In 1876, Koch demonstrated the life cycle of the anthrax bacillus and showed for the first time a specific micro-organism to be the cause of a definite disease. He was then invited to Breslau to continue his bacteriological researches, and the next three years $(1877-80)$ proved to be exciting and fruitful. In this time, Koch single-handed laid the foundations of modern bacteriological techniqueintroducing glass slides and cover slips, examination by hanging drop, fixing and staining of bacteria, culture on solid media by the poured-plate method, micro-photography, and disinfection by steam sterilisation. Using these techniques, he demonstrated streptococci and staphylococci as the common causes of wound infection. In 1880 he was appointed to the Kaiserliche Gesundheitsamt (Imperial Health Office) in Berlin (fig 1).

In August 1881, Koch attended the Seventh International Medical Congress in London, where his demonstration of his bacteriological techniques created a sensation. Even Pasteur exclaimed: "C'est un grand progrès, Monsieur!" Tuberculosis was an important subject considered at the Congress, and Koch returned to Berlin determined to find the causative organism. By March 1882 he had succeeded.

In 1883, Koch headed the German cholera commission in Egypt and India, where he isolated the cholera vibrio as the cause of the disease. By 1885 , he had been elected Professor of Bacteriology in Berlin, and the Koch Institute was built for him in 1891. There Koch attracted a host of exceptionally gifted co-workers-Gaffky, Eberth, Löffler, von Behring, Pfeiffer, Welch, Kitasato, Ehrlich, 


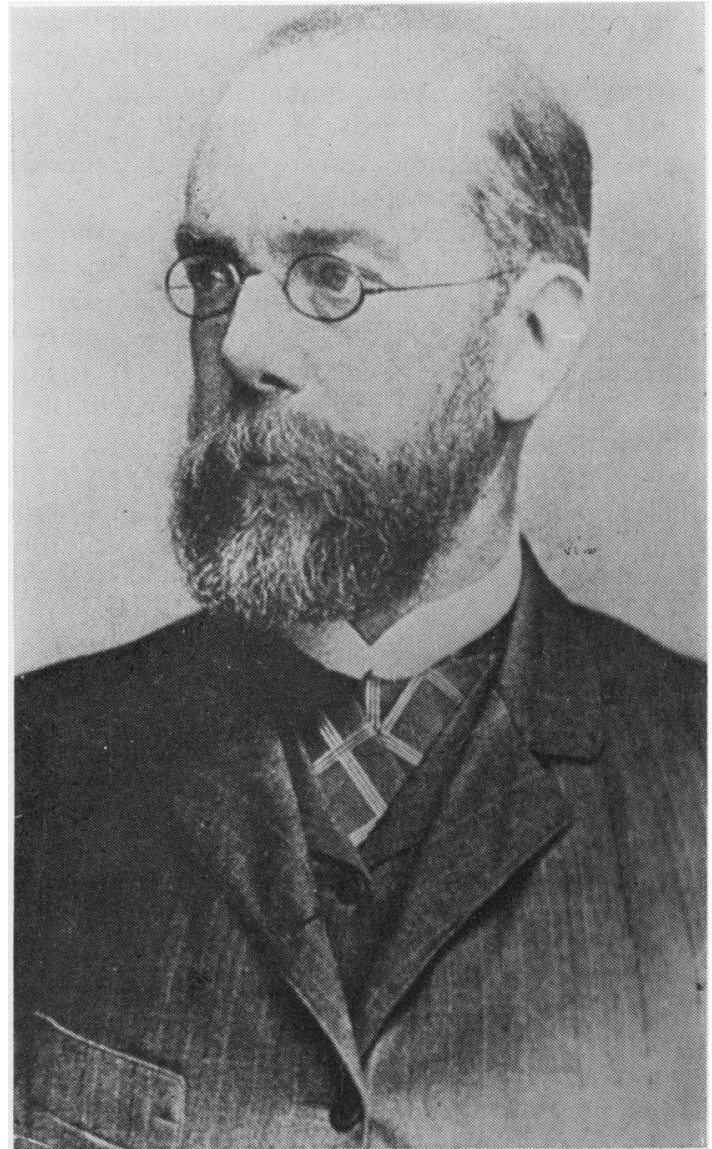

Fig 1 Robert Koch (by courtesy of the Wellcome Trustees).

Wassermann, and others. He continued his researches into tuberculosis and 1890 saw his controversial introduction of tuberculin. $\mathrm{He}$ was now travelling abroad a great deal, studying the tropical diseases of Africa and India. In 1905, he was awarded the Nobel Prize for Medicine, for his work on tuberculosis.

Koch had married Emmy Fraats in 1867 and there was one daughter, but later this marriage broke up and in 1893 he married a young actress, Hedwig Freiburg. He died in Baden-Baden on 27 May 1910, aged 67 years (fig 2).

\section{Tuberculosis before Koch}

Tuberculosis was a disease known to the ancients and Hippocrates and Galen suspected its contagious nature. In 1650, Sylvius described the tubercle, and by 1819 , Laënnec was convinced that the tubercle was the common factor in all forms of the disease, which was christened "tuberculosis" by Schönlein in 1839. Pasteur's germ theory of infectious disease (1862) provided a stimulus for the search for the causative organisms of the various infectious diseases. In the field of tuberculosis, the first major breakthrough was by Jean-Antoine Villemin (1827. 1892), who in 1865 showed by animal experiments that tuberculosis could be inoculated from man or cow to rabbit or guinea-pig, and that the sputum of a consumptive could infect a rabbit with tuberculosis. The British Government set up a commission to investigate these claims and Sir John Burdon Sanderson and Sir John Simon confirmed Villemin's findings.

In 1877, Cohnheim and Salamonsen successfully inoculated tuberculosis into the anterior chamber of a rabbit's eye and Tappeiner was able to infect dogs with tuberculosis by exposing them to inhalation of droplets of infected material. The question now was not whether tuberculosis was caused by microorganism, but who would be the first to demonstrate it. It was at this stage (1881-82) that Koch embarked on his search for the tubercle bacillus.

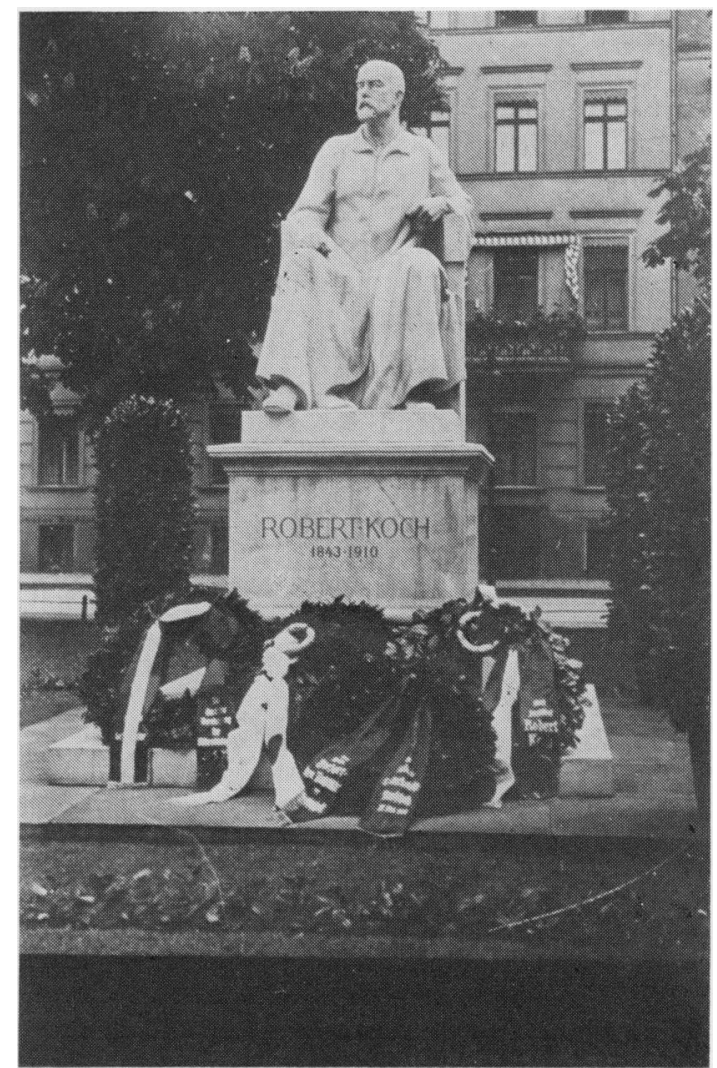

Fig 2 Robert Koch Memorial in Robert Koch Platz, Berlin. 
Discovery of the tubercle bacillus, 1882

It was on 24 March 1882 that Koch announced the discovery of the tubercle bacillus. The occasion was the monthly evening meeting of the Berlin Physiological Society. The reason why Koch presented his paper to the Physiological Society and not to the Pathological Society may have been because of his poor relationship with Rudolf Virchow, Professor of Pathology, who was the dominant figure in Berlin medicine at that time. The meeting started at $7 \mathrm{pm}$ in the reading room of the laboratories of Professor Du Bois-Reymond, who took the Chair. Among the 36 members present that evening were Helmholtz, Löffler, Ehrlich, and other famous medical figures. Koch entitled his address simply "Uber Tuberculose" and described his discovery:

"With regard to tuberculosis, it was to be expected that the discovery of pathological organisms might be attended with unusual difficulty, since many attempts had been made to demonstrate them without producing satisfactory results. I began my investigations, using material in which the infective organism would surely be expected, as for example in fresh growing grey tubercles from the lungs of animals which had died three to four weeks after infection. From such lungs, hardened in alcohol, sections were prepared and for the proof of the bacteria, the usual methods were employed. Also grey tubercles were crushed, spread on cover glass, dried and tested for the presence of micro-organisms. Efforts to find other micro-organisms in these preparations were unsuccessful."

The method Koch used to stain and demonstrate the bacilli he described thus:

"Earlier observations having shown that in certain cases the deepest staining and clearest differentiation of bacteria from surrounding tissues were yielded by the use of stains which were of alkaline reaction, advantage was taken of this fact. Of the common aniline dyes, methylene-blue bears the freest addition of alkalis, therefore this staining material was chosen; and to a watery solution of it, caustic potash was added.... When the cover-glasses were exposed to this staining fluid for 24 hours, very fine rod-like forms became apparent in the tubercular mass for the first time, having, as further observations showed, the power of multiplication and of spore formation and hence belonging to the same group of organisms as the anthrax bacillus. It was incomparably more difficult to recognise these bacilli in sections among the heaped-up nuclei and masses of detritus, and an attempt was made to render the tubercle bacilli more evident by contrast- staining according to the method by which Weigert succeeded ... by using a concentrated solution of vesuvin. Microscopic examination then showed that only the previously blue-stained cell nuclei and detritus became brown, while the tubercle bacilli remained a beautiful blue."

Orignally Koch had used an old preparation of methylene-blue, but on repeating the experiment with a fresh preparation, the bacilli were not stained. It then occurred to Koch that atmospheric ammonia had rendered the methylene blue alkaline. It was for this reason that Koch came to add caustic potash to the methylene-blue.

Culture of the tubercle bacilli proved to be difficult. Eventually Koch used the cattle-blood serum solid medium devised by Professor John Tyndall, and by the tenth to fifteenth day, very tiny colonies became visible through the magnifying lens. Koch now searched every variety of tuberculous material, both human and animal, and was gratified to find tubercle bacilli in them. He also noted that the same technique stained the leprosy bacillus, which had been identified by Armauer Hansen in 1873. However, Koch's description of spores was erroneous-what he saw must have been the small refractile bodies (bacillary segments or granules) described in 1907 by Much.

Löffler, who was present at the lecture, later described how Koch (then aged 38 years) began speaking with some diffidence, since this was his maiden speech before such a distinguished gathering. However, he was soon in his stride and the account of his experiments and findings were delivered in a cool and confident manner. When Koch finished, there was no applause or discussion, but his audience must have sensed the privilege of having been present at a historic medical occasion.

\section{World reaction to the discovery}

Seventeen days later, on 10 April 1882, Koch published the lecture in the Berliner Medicinische Wochenschrift, under the title "Die Aetiologie der o Tuberculose." The disease which had ravaged and $N$ mystified for so long had now, at long last, divulged N its secret. The news soon spread, and apart from accounts in the medical journals, the discovery hit the headlines of the world national press.

Koch had sent a copy of his paper to Professor $\cong$ John Tyndall in London, who immediately published : the essential findings in the form of a letter to The Times on Saturday 22 April 1882. The next day Sunday 23 April, the New York World carried a $\underset{\mathbb{D}}{ }$ report of the discovery, and this was copied the $\frac{\varrho}{\sigma}$ next day, Monday 24 April, in the Philadelphia Public Ledger. By 3 May, Tyndall's letter to The Times 
was reported in full in the New York Times and New York Tribune, and it was also featured in the New York Times on Sunday 7 May. As the news spread around the world, Koch became, almost overnight, a household name, and "Koch's bacillus" and "Koch's disease" entered medical jargon.

There were many (and these included Virchow) who found it difficult to accept that the bacillus which Koch demonstrated was the cause, and not merely an accompaniment, of the disease. Gradually, however, even the most dubious and sceptical were converted to the new knowledge.

As with most major scientific discoveries, there were rival claims for priority of the discovery of the tubercle bacillus. Baumgarten and Aufrecht had perhaps seen the bacillus in tuberculous material around the same time as Koch, but they were unable to stain and demonstrate it as Koch had done. As René and Jean Dubos have written: "In science the credit goes to the man who convinces the world, not to the man to whom the idea first occurs."

\section{Staining of the tubercle bacillus}

The great Paul Ehrlich (1854-1915), then assistant to Professor von Frerich at the Charité Hospital, Berlin, had been present at Koch's lecture on 24 March 1882. Ehrlich was then aged 28 years. He subsequently wrote: "The evening stands in my memory as my greatest scientific experience." During the lecture, Ehrlich recalled seeing, in various materials including sputum, bacilli similar to those demonstrated by Koch. Immediately the lecture was over, he obtained from Koch a pure culture of tubercle bacilli and that same evening he hastened to his laboratory at the Charité and experimented with various stains. Ehrlich had already devised a stain for mast cells, using aniline water, fuchsin and gentian-violet. He now experimented with these stains to demonstrate tubercle bacilli. He used a shorter staining time (15 to 30 minutes, instead of Koch's 24 hours) and he also applied $30 \%$ nitric acid and alcohol for a few seconds in order to decolourise the surrounding tissues, while the tubercle bacilli retained their stain. On counterstaining with a yellow or blue dye, the red tubercle bacilli showed up more clearly than by Koch's method.

It was by accident that Ehrlich learned of the benefit of heating the slide. In his laboratory there was a small iron stove in which the fire had been out for some hours that evening. Before returning home, he placed the stained preparations to dry on the top of the cold stove. The next morning he was annoyed to find that the stove had been lit, but when he examined the slides he was astonished to find the bacilli in clumps showing up even more clearly. Ehrlich hastened to tell Koch, who immediately realised that Ehrlich's staining method (using heat and decolourising with acid) was superior to his own. Shortly afterwards, in May 1882, Ehrlich published details of the technique. Later Ziehl introduced carbolic instead of aniline, while Neelsen advocated the use of sulphuric instead of nitric acid. In this way, the "Ziehl-Neelsen" (ZN) stain and the "acidalcohol fast bacillus" (AAFB) were born.

Koch wrote later (1883):

"It was soon found that with Ehrlich's method of staining, the recognition of tubercle bacilli could readily be made use of in diagnosis. We owe it to this circumstance alone that it has become a general custom to search for the bacilli in the sputum, whereas without it, it is likely that but few investigators would have concerned themselves with tubercle bacilli."

It is of interest that, in 1887, Ehrlich tested his own sputum, in which he found tubercle bacilli, diagnosed pulmonary tuberculosis, and proceeded to Egypt, where he stayed for two years and then returned cured.

Koch had a dry sense of humour, and when once asked how long it was necessary to flame a slide when staining for the tubercle bacillus, he replied, with a twinkle in his eye: "As long as it takes to say: 'Robert Koch is a great man!",

\section{"Die aetiologie der tuberculose"}

After publication of his first paper on the tubercle bacillus in April 1882, Koch continued his researches in tuberculosis. In 1884, he published a more comprehensive paper, "Die Aetiologie der Tuberculose," in the second volume of Mittheilungen aus dem Kaiserliche Gesundheitsamt (Reports of the Imperial Health Office).

In his 1882 paper, Koch had omitted to give adequate credit to previous research workers and was especially criticised for his perfunctory reference to the important experiments of Villemin. This omission may well have had nationalist and political undertones. He did however make passing reference to the work of his own countrymen, Cohnheim, Salamonsen, Baumgarten, and Tappeiner. However, in the fuller 1884 paper, Koch rectified this, and gave credit to all, including John Tyndall, and especially to Ehrlich for his staining technique, which superseded Koch's original methylene-blue method. It was in this classic paper, a masterpiece of medical literature, that Koch described his postulates -the stringent criteria which an organism must fulfil before it can be considered to be the cause of an infectious disease: (1) the organism must be isolated 
from the diseased tissues in every case of the disease; (2) the organism must be grown in pure culture; (3) inoculation of a susceptible animal with the organism must reproduce the same disease; $(4)$ the organism must be recovered from the infected animal and be grown again in pure culture.

\section{Koch and tuberculin}

Although Koch was involved later with many other bacteriological problems, he continued to take a special interest in tuberculosis.

In 1890, the Tenth International Medical Congress was held in Berlin, where Koch read a paper "On Bacteriological Investigation". It was on this occasion that he dropped a bombshell by announcing that he had a substance which hindered the growth of tubercle bacilli, cured tuberculosis in infected guinea-pigs and would probably be useful in the treatment of human phthisis, especially in its early stages.

Later, in the autumn of 1890 , Koch published a paper on the subject which began:

"In a communication which I made a few months ago to the International Medical Congress, I described a substance of which the result is to make laboratory animals insensitive to inoculation of tubercle bacilli, and in the case of already infected animals, to bring the tuberculous process to a halt."

What Koch described was known later as the "Koch Phenomenon"-that is, resistance of an infected animal to reinfection. Koch at first gave no details of the preparation or composition of this substance, which he considered had diagnostic as well as therapeutic potential, and he emphasised that his researches were not yet concluded. The substance came to be referred to as "Koch's Lymph." However, so much pressure, both national and international, was brought to bear upon him that by January 1891 , he published a further paper which divulged that the substance was a filtrate from a growth of tubercle bacilli on glycerol broth. The name "Tuberculin" had originally been voiced by Pohl Pincus in 1884, but it was resurrected by Bujwid in 1891, and Koch decided to adopt the name. This is the substance which came to be known as Old Tuberculin (OT).

The announcement of a cure for tuberculosis, coming from a medical scientist of such distinction as Koch, immediately excited interest throughout the world. A Lancet editorial welcomed the news as "glad tidings of great joy" and the British Medical Journal was no less enthusiastic. Both journals published a complete translation of Koch's paper. Koch's announcement produced a profound sensation on the Mediterranean Riviera. The English Review of Reviews in its December 1890 issue described how:

"The news that the German scientist had discovered a cure for consumption must have sounded as the news of the advent of Jesus of Nazareth in a Judean village. The whole community was moved to meet him. His fame went throughout the region, and telegrams in the newspapers announced that all the sleeping cars had been engaged for months to convey the consumptives of the Riviera to the inclement latitude of Berlin."

The English physician and writer Sir Arthur Conan Doyle travelled to Berlin to investigate the claims, and Sir Joseph (later Lord) Lister took his tuberculous niece to Berlin, so that Koch could treat her himself. In the United States, 1000 dollars were offered for a teaspoon of the remedy. William Osler, then Professor at Johns Hopkins, Baltimore, had received from abroad two small bottles of tuberculin, and he generously sent one to Trudeau for him to try out on his consumptives at Saranac Lake.

With such international excitement, the news that tuberculin was producing severe reactions and, far from being a magic cure, was making many patients worse, came as a dreadful let-down. High hopes were followed by sad disappointments, and Koch became the object of considerable criticism and even abuse. Koch defended himself by maintaining that he had never claimed tuberculin to be a universal cure for all cases of tuberculosis.

Koch nevertheless continued his researches, trying to improve on his original tuberculin, and by 1907 he produced what he considered to be a better version, New Tuberculin, first Tuberculin Residue (TR) and later Bacillary Emulsion (BE), but when these were tested on patients they too proved to be disappointing. Eventually, Koch gave up completely the use of tuberculin as a cure. However, tuberculin was to prove to be of enormous value as a diagnostic tool to distinguish the infected from the noninfected, especially when BCG vaccination was later introduced. Moreover, the study of the tuberculin reaction paved the way for subsequent research on allergy and immunity.

\section{Human versus bovine tubercle bacillus controversy}

When Koch first described the tubercle bacillus in 1882 , he considered that human and bovine bacilli were separate organisms, confirming what had already been established by Villemin in 1865 . However, in his 1884 paper, Koch concluded that the bacilli of human and bovine disease were identical; but, despite the fact that bovine tuberculosis was 
transmissible to man, he did not feel that such infection was an important human hazard.

In 1898 Professor Theobald Smith of Harvard published his findings on human and bovine tubercle bacilli and clearly demonstrated them to be different organisms. In 1901 the Third International Tuberculosis Congress was held in London. Koch spoke at this Congress and accepted the findings of Theobald Smith, but still maintained that tuberculosis in cattle was not an important danger to man and special preventative measures were unnecessary. This view provoked considerable opposition at the time. Lord Lister, who presided at the Meeting, opened the discussion and questioned Koch's views. When tackled later, Koch maintained that he had meant that the bovine bacillus was only relatively less important than the human variety, which was responsible for the great majority of cases of infectious phthisis.

Considerable controversy ensued as to what Koch had really said at the Congress. In 1903, the Privy Council set up a Royal Commission on Tuberculosis and its final report in 1911 refuted Koch's alleged views, which had obviously underestimated the seriousness of bovine tuberculosis as a public health hazard. The Royal Commission recommended measures which were later put into effect by a policy of eradication of infected cattle and the pasteurisation of milk. A German Commission came to the same conclusions. Yet in 1908, at the Washington Congress on Tuberculosis, Koch still maintained that infection of man by the bovine bacillus was negligible and did not justify special preventative measures.

\section{Conclusion}

The science of bacteriology owes its origin to two men of genius, Louis Pasteur and Robert Koch. As Webb has written, Pasteur may be described as master-architect and Koch as master-builder of the science. In the field of tuberculosis, Koch's discovery of the tubercle bacillus and tuberculin revolutionised the management of this disease.

On the occasion of the centenary of the discovery of the tubercle bacillus, we salute Robert Koch whose contributions to bacteriology and tuberculosis place him among the medical immortals.

\section{Selected bibliography}

Aufrecht E. Die aetiologie der tuberculose. Centralblatt fur der Medicinischen Wissenschaften 1882; no 17 (April 29).

Baumgarten P. Tuberkelbakterien. Centralblatt fur der Medicinischen Wissenschaften 1882; no 15 (April 15).

Brown L. Robert Koch: an American tribute. Ann Med Hist 1935;7:93-112, 292-304, 385-401.

Bulloch W. The history of bacteriology. New York: Oxford University Press, 1938.
Cummins SL. Tuberculosis in history. London: Baillière, Tindall and Cox, 1949.

Dubos R, Dubos J. The white plague: tuberculosis, man and society. London: Gollancz, 1953.

Ford WW. The life and work of Robert Koch. Johns Hopkins Hospital Bulletin 1911;22:415-25.

Gaffky G. Robert Koch. Dtsch Med Wochenschr 1910;36: 2321-4.

Keers RY. Pulmonary tuberculosis: a journey down the centuries. London: Baillière, Tindall, 1978.

Knopf SA. Robert Koch: the father of the modern science of tuberculosis. Johns Hopkins Hospital Bulletin 1911;22; 425-8.

Landis HRM. The reception of Koch's discovery in the United States. Ann Med Hist 1932;4:531-7.

Marquardt M. Paul Ehrlich. New York: Schuman, 1951.

Paltauf R. Robert Koch. Wien Klin Wochenschr 1903;16: 1377-81.

Sakula A. Robert Koch: founder of the science of bacteriology and discoverer of the tubercle bacillus. $\mathrm{Br} J \mathrm{Dis}$ Chest 1979;73:389-94.

Sakula A. Baroness Burdett-Coutts' garden party. International Medical Congress, London, 1881. Med Hist 1982;26:183-90.

Smith T. Koch's views on the stability of species among bacteria. Ann Med Hist 1932;4:524-30.

Transactions of Third International Congress on Tuberculosis. London 1901;1:27.

Webb GB. Robert Koch. Ann Med Hist 1932;4:509-23.

Wezel E. Robert Koch: eine biographische studie. Berlin: Hirschwald, 1912.

Ziehl F. Zur färbung des tuberkelbacillus. Dtsch Med Wochenschr 1882;8:451-3.

Appendix

KOCH'S PUBLICATIONS ON TUBERCULOSIS

1882 Die aetiologie der tuberculose. Berliner Klinische Wochenschrift 19;221-30.

1883 Kritische besprechungen der gegen die bedeutung der tuberkelbazilien gerichteten publicationen. Dtsch Med Wochenschr 9;137-41.

1884 Die aetiologie der tuberculose. Mittheilungen aus dem Kaiserlichen Gesundheitsamt 2;1-88.

1890 Weitere mittheilungen uber ein heilmittel gegen tuberculose. Dtsch Med Wochenschr 16;1029-32.

1891 Forsetzung der mittheilungen uber ein heilmittel gegen tuberculose. Disch Med Wochenschr 17:101-2.

1891 Weitere mittheilung uber das tuberkulin. Dtsch Med Wochenschr 17;1189-92.

1897 Uber neue tuberkulin präparate. Dtsch Med Wochenschr 23;209-13.

1901 Die bekämpfung der tuberculose unter berücksichtung der erfarungen, welche bei der erfolreiden bekämpfung anderer infektionskrankheiten gemacht sind. (Vortrag gehalten auf dem britische tuberculose-congress). Dtsch Med Wochenschr 27;549-54.

1901 Uber die agglutination der tuberkelbazillen und uber die verwerthung dieser agglutination. Dtsch Med Wochenschr 27;829-34.

1905 (With Schütz W, Neufeld F, Miessner H.) Uber die immunisierung von rindern gegen tuberculose. Zeitschrift fur Hygiene und Infektionskrankheiten 51;300-27.

1906 Uber die rolle der milch bei der ubertragung der tuberculose auf menschen. Molkerei-Zeitung 16;37.

1910 Epidemiologie der tuberculose. (Vortrag gehalten in der sitzung der akademie der wissenschaft, zu Berlin am 7 April 1910). Zeitschrift fur Hygiene und Infektionskrankheiten 67;1-48. 